\title{
The end of a long controversy: systematics of the genus Limenandra (Mollusca: Nudibranchia: Aeolidiidae)
}

\author{
Leila Carmona - Marta Pola - Terrence M. Gosliner • \\ Juan Lucas Cervera
}

Received: 2 June 2013/Revised: 21 July 2013/Accepted: 22 July 2013/Published online: 7 August 2013

(C) Springer-Verlag Berlin Heidelberg and AWI 2013

\begin{abstract}
Limenandra Haefelfinger and Stamm 1958 is a small genus within the Aeolidiidae with, until this paper, only two species: Limenandra nodosa Haefelfinger and Stamm 1958 and Limenandra fusiformis Baba 1949. Although most recent authors have regarded Limenandra as a junior synonym of Baeolidia Bergh 1888, recent molecular studies have demonstrated its monophyletic status and have rejected the circumtropical distribution attributed to the type species, L. nodosa. The present paper reviews the previously known species of Limenandra with additional morphological data and describes three new species: Limenandra barnosii sp. nov. and Limenandra rosanae sp. nov. from the Indo-Pacific are easily distinguished from all other Limenandra species by their vivid and bright colour patterns, while Limenandra confusa sp. nov., also from the Indo-Pacific, is very similar to the
\end{abstract}

This is CEI.MAR journal publication 30 .

Communicated by H.-D. Franke.

L. Carmona $(\bowtie)$. J. L. Cervera

Departamento de Biología, Facultad de Ciencias del Mar y Ambientales, Campus de Excelencia Internacional del Mar (CEI-MAR), Universidad de Cádiz, Polígono Río San Pedro, s/n, Ap.40, 11510 Puerto Real, Cádiz, Spain

e-mail: leila.carmona@uca.es

\section{Pola}

Laboratorio de Biología Marina, Departamento de Biología, Edificio de Biología, Campus de Excelencia Internacional UAM+CSIC, Universidad Autónoma de Madrid, C/Darwin, 2, 28049 Madrid, Spain

T. M. Gosliner

Department of Invertebrate Zoology, California Academy of Sciences, 55 Music Concourse Drive, Golden Gate Park, San Francisco, CA 94118, USA
Atlantic and Mediterranean L. nodosa. The five species differ in colouration, the size and ornamentation of the cerata, the rhinophorial papillae, details of the reproductive system and the number of salivary glands. Additionally, Limenandra can be easily distinguished from other Aeolidiidae based on differences in the radular and receptaculum seminis morphology.

Keywords Species complex - Cladobranchia . Molluscan diversity $\cdot$ Morphology $\cdot$ New species . Taxonomy

\section{Introduction}

Haefelfinger and Stamm (1958) erected the aeolidiid genus Limenandra, with $L$. nodosa as the type species, and transferred Baeolidia fusiformis Baba, 1949 to this new genus. They diagnosed the genus Limenandra as elongate animals, with papillate rhinophores, fusiform cerata arranged in rows and monoseriate radula. Nevertheless, many authors have considered Limenandra as a junior synonym of Baeolidia. Odhner (in Franc 1968), for instance, included Baeolidia, but not Limenandra in his "Spurillidae". Gosliner (1980) also regarded Limenandra as a junior synonym of Baeolidia and maintained this classification with the aeolidiids from South Africa (Gosliner 1985). Many recent comprehensive field guides also report L. nodosa and L. fusiformis as Baeolidia species (Redfern 2001; Camacho-García et al. 2005; Valdés et al. 2006; Gosliner et al. 2008). In fact, since the original description of $L$. nodosa, no other species has been attributed to this genus. Recently, the first comprehensive phylogenetic study of the Aeolidiidae (Carmona et al. 2013) demonstrated the validity of Limenandra and its 
monophyletic status using molecular data. The present study provides an in-depth look at the taxonomy of the genus and describes three new species from the eastern Pacific and Indo-Pacific.

\section{Materials and methods}

Literature review

A comprehensive review of the literature was conducted to determine the valid names for the species recognized in the molecular and morphological analyses. After the description of the type species, all available names for Limenandra species are discussed according to the year of publication. In the synonymy lists, references to the original description of the valid name and all synomyms (basionyms and primary synonyms) and the first proposed change of binomen (secondary synonyms) are included, but subsequent references are not.

Source of specimens and morphology

Samples were collected by SCUBA diving with standard sampling techniques for opisthobranchs and through the study of museum collections. When possible, two or more specimens of each species were examined anatomically. Specimens were dissected by dorsal incision. Their internal features were examined and drawn using a dissecting microscope with the aid of a camera lucida. Special attention was paid to the morphology of the reproductive system and the oral and salivary glands. The buccal mass was removed and dissolved in $10 \%$ sodium hydroxide until the radula was isolated from the surrounding tissue. The radula was then rinsed in water, dried, and mounted for examination by scanning electron microscopy (SEM).

The specimens examined are deposited in the California Academy of Sciences, CASIZ (San Francisco, USA), Museo Nacional de Ciencias Naturales, MNCN (Madrid, Spain), Museo de Zoología de la Universidad de Costa Rica, MZUCR (San José, Costa Rica) and Zoologische Staatssammlung München, ZSM (Munich, Germany).

\section{Results}

Systematics

Nudibranchia Cuvier 1817

Cladobranchia Willan and Morton 1984

Family Aeolidiidae Gray 1827

Genus Limenandra Haefelfinger and Stamm, 1958. Type species: L. nodosa Haefelfinger and Stamm, 1958.
Diagnosis of the genus Limenandra according to Haefelfinger and Stamm (1958).

Body thin and elongate; foot corners tentaculiform; rhinophores papillate; cerata arranged in $8-25$ rows, fusiform and rounded; radular teeth pectinate without a central cusp; masticatory edge of jaw smooth; ptyaline glands (here considered as oral glands) elongate.

Limenandra nodosa Haefelfinger and Stamm 1958 (Figs. 1a, 2a, 3a, b, 4a)

Limenandra nodosa Haefelfinger and Stamm 1958: 418, Fig. 1

Baeolidia nodosa (Haefelfinger and Stamm 1958): Gosliner 1980: 66, Fig. 19

Material examined MNCN 15.05/63448, one specimen, dissected, immature, $13 \mathrm{~mm}$ in length alive, France, Cap Ferret, 21.vii.10, collected by Marina Poddubestkaia; CASIZ 186792, one specimen, dissected, immature, $2 \mathrm{~mm}$ in length preserved, Portugal, Funchal District, Madeira, collected by Peter Wirtz 18.ix.11; MZUCR 8344, one specimen, dissected, $4 \mathrm{~mm}$ in length alive, Costa Rica, Gandoca-Manzanillo, Provincia de Limón, Punta Mona, collected by Yolanda Camacho-García, 16.v.11; CASIZ 184521, one specimen, $8 \mathrm{~mm}$ in length alive, Bahamas, Abaco, collected by Colin Redfern, 02.viii.00; MNCN $15.05 / 63449$, one specimen, dissected, $8 \mathrm{~mm}$ in length alive, Bahamas, Abaco, collected by Colin Redfern, 09.viii.00; MNCN 15.05/63450, one specimen, immature, $4.5 \mathrm{~mm}$ in length alive, Bahamas, Abaco, collected by Colin Redfern, 18.viii.03.

Geographical distribution Originally described from the Mediterranean (Haefelfinger and Stamm 1958), this species is also known from the Atlantic coast of France (present study), the Madeira Is. (present study), the Canary Is. (Cervera et al. 2004), Bahamas (Redfern 2001), the Caribbean (Valdés et al. 2006), the Atlantic coast of Costa Rica (present study) and Curaçao (Er. Marcus and Ev. Marcus 1970).

Those specimens from the Pacific reported as L. nodosa (Gosliner 1980; Camacho-García et al. 2005; Gosliner et al. 2008) are here identified as $L$. confusa sp. nov., a cryptic species of $L$. nodosa (see below).

External morphology (Figs 1a, 2, 3a, 4): The body is elongate and slender, tapering close to the tail. The anterior margin of the foot is rounded. The tentaculiform foot corners have a deep groove across width (Fig. 2). The body is dull olive green with small white spots over the entire surface. Some specimens are whitish background with dull olive green spots scattered over the notum. The dorsal surface of the body from head to tail has series of concentric circles that are, from outside to inside, white, yellow (sometimes absent), red and white in the centre. The 

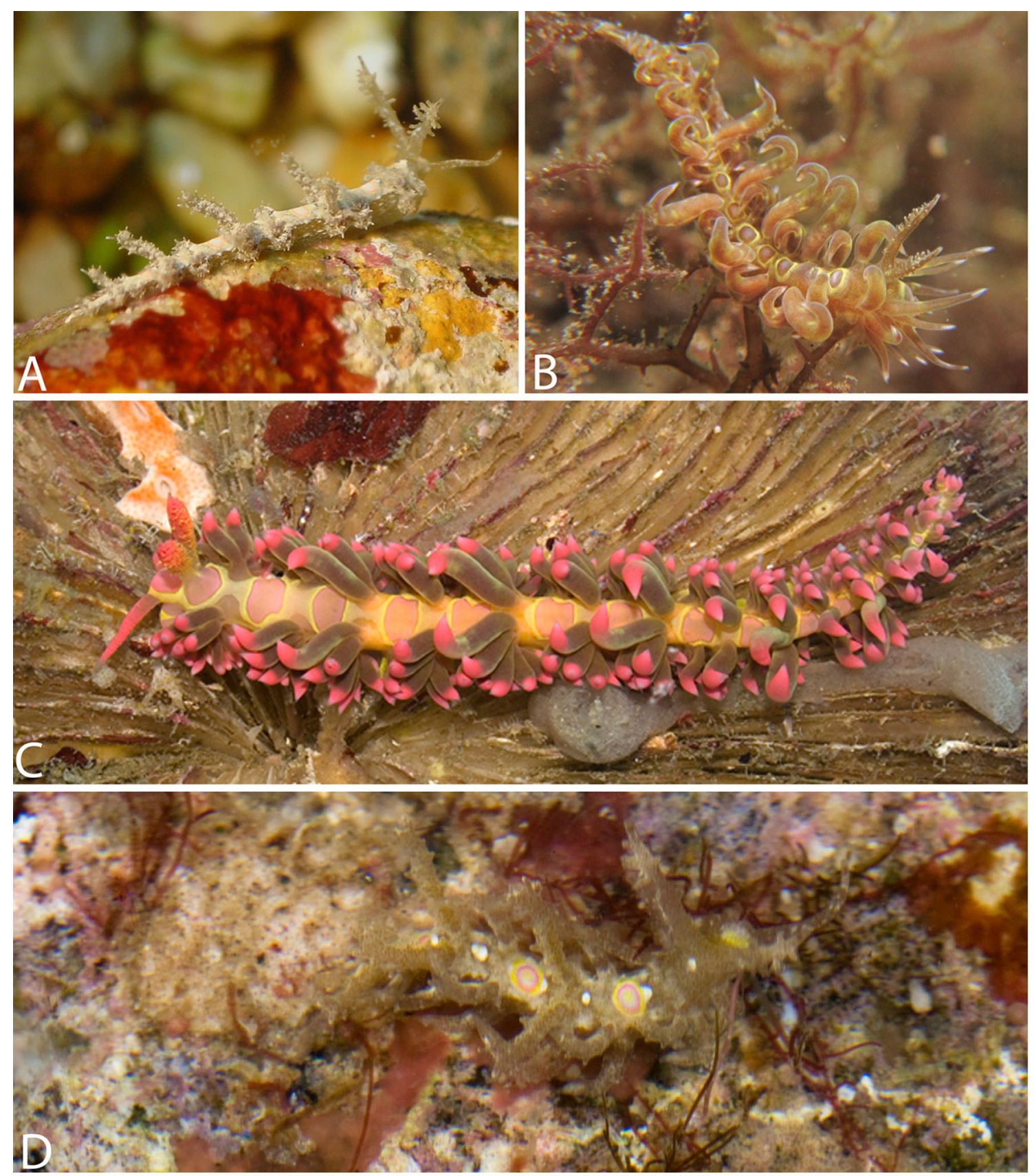

Fig. 1 Photographs of the living animals. a $L$. nodosa, specimen from France, Cap Ferret, photograph by Marina Poddubetskaia, MNCN 15.05/63448; b L. fusiformis, specimen from Japan, photograph by Shin Minowa, CASIZ 184526; c L. barnosii sp. nov.,

number of circles varies with the size of the animal. The rhinophores are dull green with numerous small white spots. The posterior side of the rhinophores has sparse, elongate and occasionally bifurcated papillae (Fig. 3a). The apex is rounded, white or cream. The oral tentacles are elongate and longer than the rhinophores. The oral tentacles and the foot corners have the same colour as the body with opaque white spots. specimen from the Philippines, photograph by Terrence M. Gosliner, CASIZ 177682; d $L$. confusa sp. nov., specimen from the Philippines, photograph by Terrence M. Gosliner, CASIZ 181280

The cerata are dorsoventrally flattened and some of them are papillate (Fig. 4). They have the same colour as the body covered by white spots. Some specimens have light green pigment over the ceratal surface and one pink spot on the anterior side, close to the base. The cerata are arranged in up to eight rows, from just behind the rhinophores to the end of the foot. The first two rows are very close together. The cerata of rows IV, VI, VIII and X (sometimes absent) 


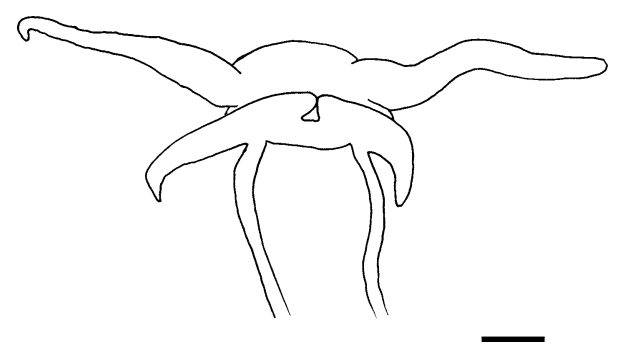

Fig. 2 Ventral view of the anterior margin of the foot. Scale bar $0.5 \mathrm{~mm}$

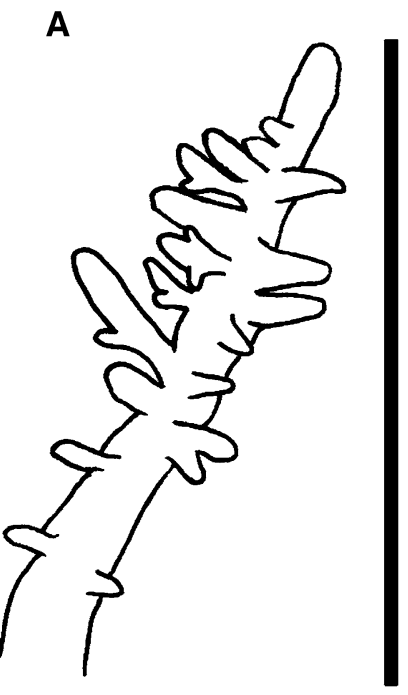

B

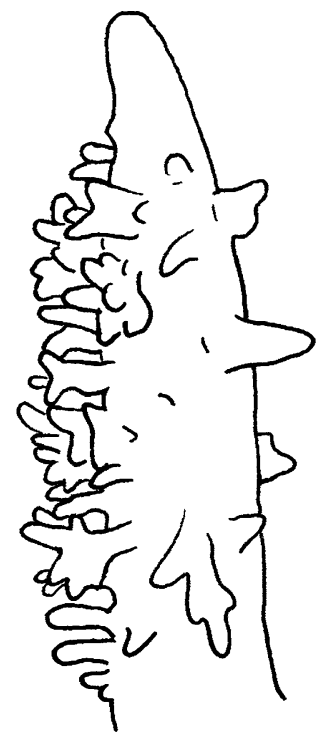

Fig. 3 Different papillate rhinophores in Limenandra. a Scale bar $3.5 \mathrm{~mm}$; b from Haefelfinger and Stamm (1958)

are much longer than the rest of the cerata. Each row contains 1-5 cerata, decreasing in size towards the foot. The anus is cleioproctic and is located behind the third right row. The gonopore is located between rows II and III on the right side.

Anatomy The jaws have a denticulate masticatory border (Fig. 5a). The radular formulae are $5 \times 0.1 .0$ (CASIZ 186792), $6 \times 0.1 .0$ (MZUCR 8344) and $7 \times 0.1 .0(\mathrm{MNCN}$ 15.05/63449). The radular teeth have a total of 21-27 moderately broad denticles (MNCN 15.05/63449) (Fig. $5 b$ ). The teeth are progressively smaller to the posterior region of the radula. The oral glands lie dorsolaterally to the buccal bulb. They are elongate, tapering towards the proximal end.

The reproductive system is diaulic (Fig. 6a). The preampullary duct widens into the conspicuous but short ampulla. The postampullary duct narrows before dividing into the oviduct and the vas deferens. The long vas deferens enters the wider proximal portion of the penial sac, which contains the unarmed penial papilla. The short

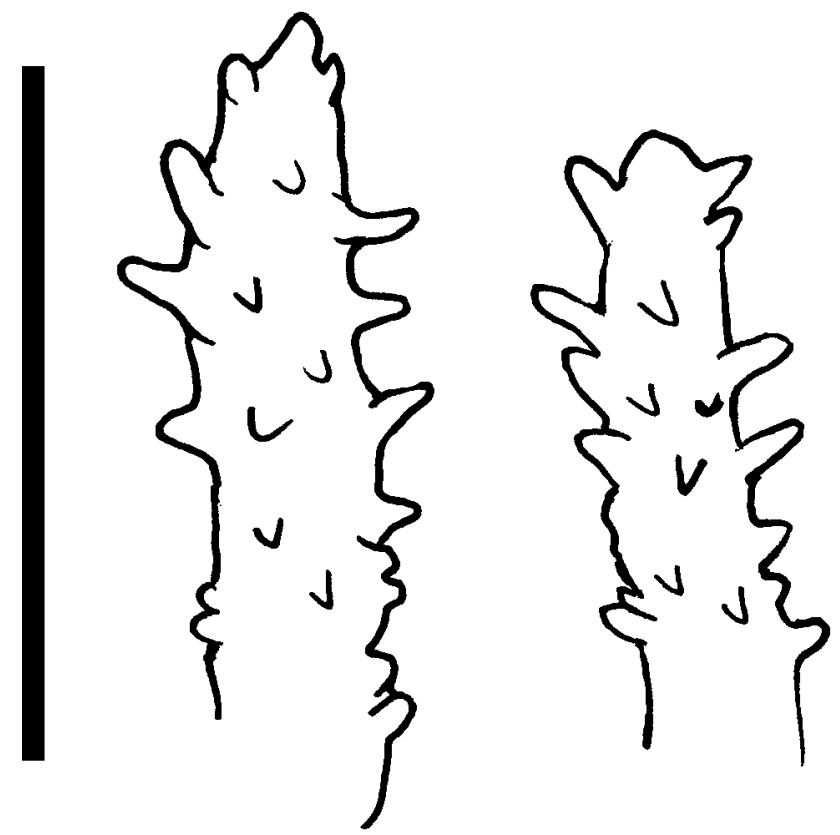

Fig. 4 Detailed view of the papillate cerata of $L$. nodosa and $L$. confusa. Scale bar $2 \mathrm{~mm}$

oviduct gives off a duct to the circular receptaculum seminis before entering the female gland. The proximal part of the duct to the receptaculum appears to have a swelling of unknown function. The vagina opens ventral to the penis.

Remarks Haefelfinger and Stamm (1958) erected this new species based on 60 specimens found at Villefranche and Beaulieu (France, Mediterranean). They illustrated the external appearance of $L$. nodosa, its rhinophores, radular teeth and jaws. These authors described a non-denticulate masticatory border, but they also reported light stretch grooves. In the specimens that we dissected, we found smooth, denticulate (Fig. 3a) as well as striated masticatory borders, so there is considerable intraspecific variation, which is very common within the Aeolidiidae (GarcíaGómez and Cervera 1985), but has not been reported previously for $L$. nodosa. The oral glands reported by Haefelfinger and Stamm (1958) were only observed in one of the specimens examined in this study. Although these differences could be produced by subjective misinterpretation, similar variability has also been found in species of Baeolidia (personal observation).

Schmekel (1970) described a penial gland in the reproductive system of $L$. nodosa. This species together with Baeolidia moebii (identified as Berghia major) is thought to be the only aeolidiids with this gland (Gosliner 1985). However, we could find no trace of a penial gland in any of the specimens examined here (Fig. 4a). Schmekel (1970) considered that the second and small lobe of the 

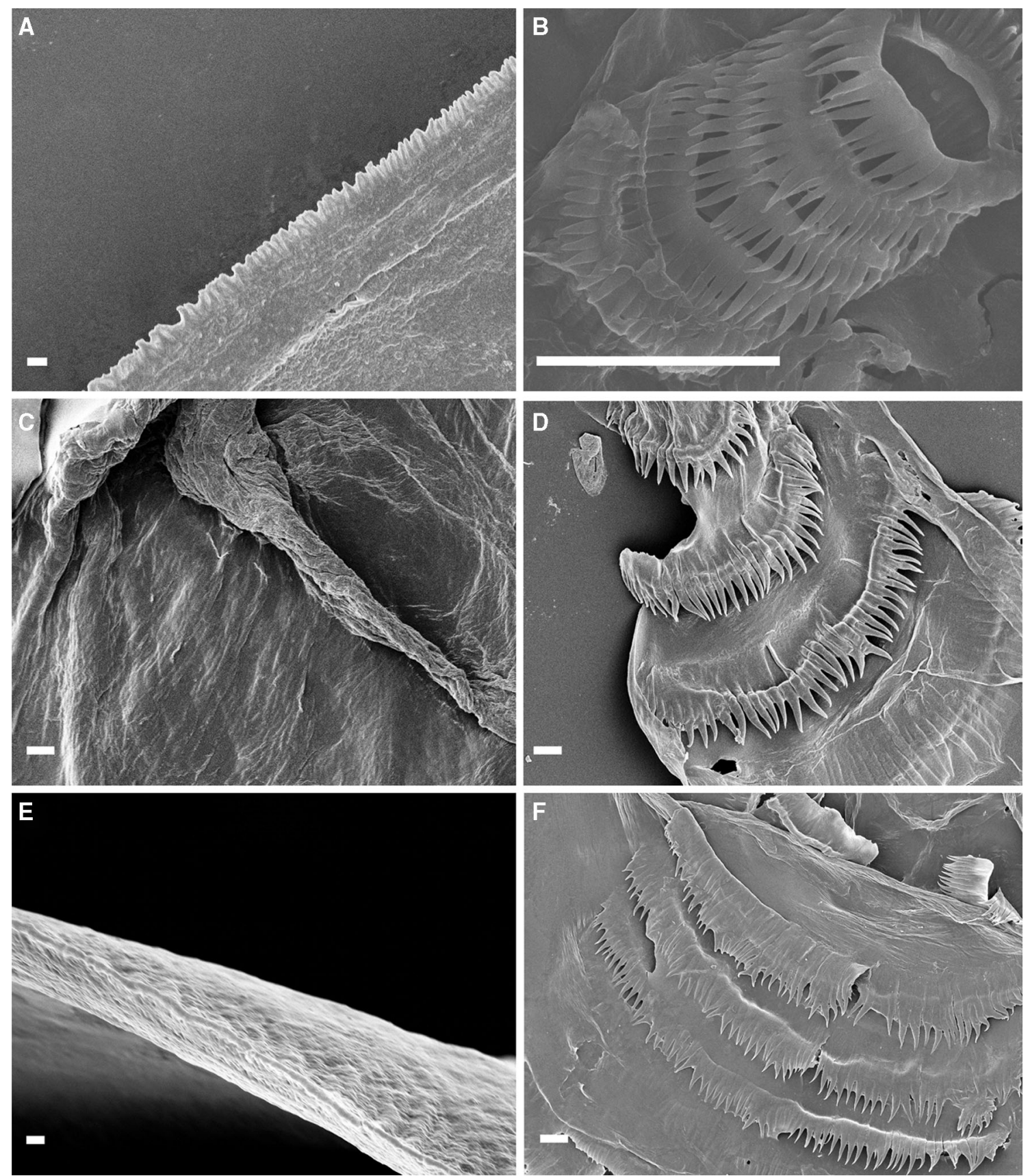

Fig. 5 Scanning electron photographs. a, b $L$. nodosa; a detailed view of the masticatory border (CASIZ 186792), scale bar $=2 \mu \mathrm{m}$; b radular teeth (MNCN 15.05/63449), scale bar $50 \mu \mathrm{m}$; c, d $L$. fusiformis (CASIZ 184526); c detailed view of the masticatory

receptaculum seminis (Fig. 6a) was a wider part of the duct of the receptaculum seminis. This feature, which was described as a "loop" by Schmekel and Portmann (1982), is corroborated by our study.

Our L. nodosa specimens clearly match the available descriptions (Haefelfinger and Stamm 1958; Templado 1982; Schmekel and Portmann 1982). Only size varies. border, scale bar $10 \mu \mathrm{m}$; d radular teeth, scale bar $10 \mu \mathrm{m}$; e, f $L$. barnosii sp. nov. (CASIZ 177682); e detailed view of the masticatory border, scale bar $2 \mu \mathrm{m}$; $\mathbf{f}$ radular teeth, scale bar $20 \mu \mathrm{m}$

While those specimens collected by Haefelfinger and Stamm (1958) reached $25 \mathrm{~mm}$, our specimens are $13 \mathrm{~mm}$ maximum. Moreover, so far, it is the only Limenandra species reported from the Mediterranean and Atlantic. This restricted distribution distinguishes L. nodosa from its sibling species from the Pacific (see L. confusa remarks). 
Fig. 6 Reproductive system. a $L$. nodosa, specimen from Bahamas (MNCN 15.05/ 63449), scale bar $0.5 \mathrm{~mm}$; b $L$. fusiformis, specimen from United Arab Emirates (CASIZ 190512), scale bar $0.5 \mathrm{~mm}$; $c$. barnosii sp. nov., specimen from the Philippines, (CASIZ 177682), scale bar $0.5 \mathrm{~mm} ; \mathbf{d} L$. confusa sp. nov., specimen from Midway Island (CASIZ 088358), scale bar $0.75 \mathrm{~mm}$; e $L$. rosanae sp. nov., specimen from the Marshall Islands (CASIZ 184522), scale bar $1 \mathrm{~mm}$. am ampulla, fgm female gland mass, $p s$ penial sac, $r s$ receptaculum seminis, $v a$ vagina, $v d$ vas deferens
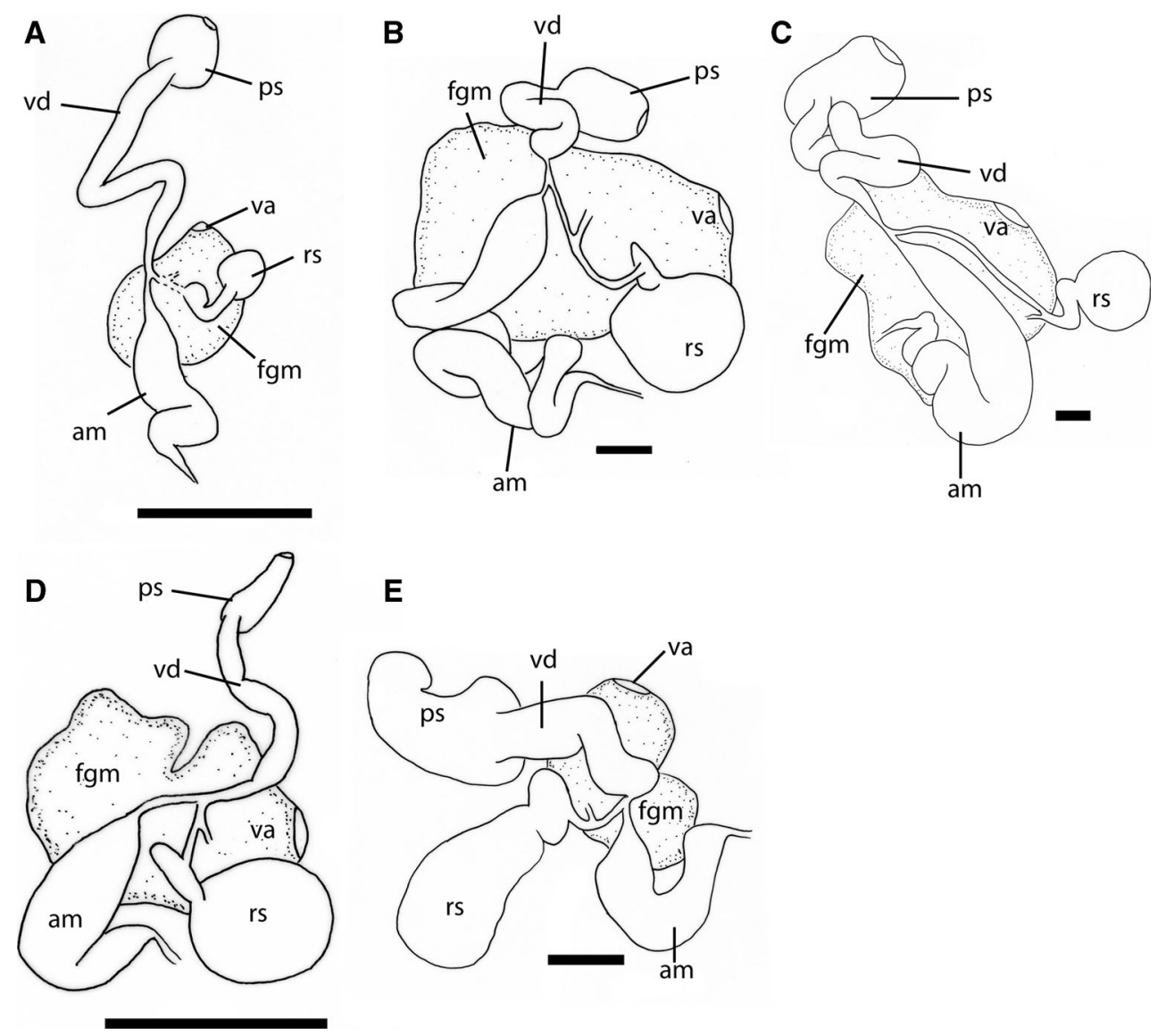

E

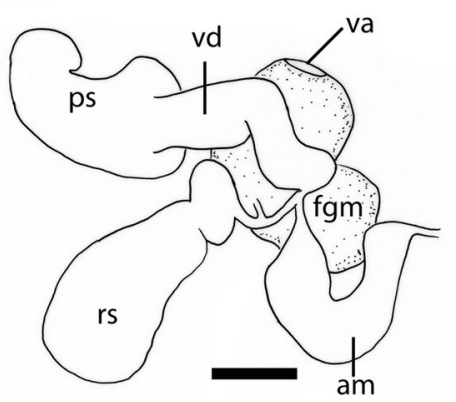

Limenandra fusiformis (Baba 1949) (Figs. 1b, 2, 3b, 5c, $\mathrm{d}, 6 \mathrm{~b})$

Baeolidia fusiformis Baba 1949: 184, pl. L, Fig. 169

Limenandra fusiformis (Baba 1949): Haefelfinger and Stamm 1958, 421

Material examined CASIZ 184526, two specimens, dissected, $20 \mathrm{~mm}$ in length alive, Japan, Chiba Prefecture, Myogane-misaki Cap, collected by Shin Minowa, 29.vii.10; CASIZ 190512, one specimen, dissected, $3 \mathrm{~mm}$ in length preserved, United Arab Emirates, East Coast, Gulf of Oman, collected by Carole Harris February 2005.

Geographical distribution Originally described from Japan (Baba 1949; Nakano 2004; Ono 2004), it is also known from the Red Sea (Yonow 2000, 2008).

External morphology (Figs. 1b, 2, 3b): The body is thin and slender, tapering close to the tail. The anterior margin of the foot is rounded. The foot corners are tentaculiform and have a deep groove across width (Fig. 2). The body colour is pale brown with bright yellow spots over the dorsum. The dorsal surface of the body from head to tail has series of concentric circles that are, from outside to inside, bright yellow, pale brown and white in the centre. The number of circles depends on the size of the animal. The rhinophores are ashy brown with small bright yellow spots. They are densely papillate on posterior side and the white apex is rounded. These papillae are elongate, not uniform in size, and occasionally bifurcated (Fig. 3b). The oral tentacles are elongate and longer than rhinophores. Both oral tentacles and foot corners are brownish with opaque yellow patches.

The cerata are moderately long, fusiform and rounded. Some cerata are noticeably longer than the rest. Their tips are sharply recurved inwards. The cerata have the same colour as the body colour covered by bright yellow spots, with white cnidosacs. They are arranged in up to fifteen rows, from just behind the rhinophores to the end of the foot, separated by a space. Each row contains 5-11 cerata, decreasing in size towards the foot. The cleioproctic anus is located behind the third right row. The genital opening is placed between rows II and III on the right.

Anatomy The masticatory edge of the jaws is devoid of denticles (Fig. 5c). The radular formula is $8 \times 0.1 .0$ (CASIZ 184526, $20 \mathrm{~mm}$ ). The radular teeth have a total of 15-56 moderately broad denticles (Fig. 5d). The teeth are 
progressively smaller to the posterior region of the radula. The oral and salivary glands are absent.

The reproductive system is diaulic (Fig. 6b). The preampullary duct widens into a very long and convoluted ampulla. The postampullary duct forks into the oviduct and vas deferens. The short and wide vas deferens enters the wider proximal portion of the penial sac, which contains the unarmed penial papilla. A long oviduct connects to a large and ball-shaped receptaculum seminis with a basal swelling. The remaining portion of the oviduct departs from the base of the receptaculum and enters the female gland. The vagina opens ventral to the penis.

Remarks Limenandra fusiformis was first described under the name of B. fusiformis (Baba 1949). Baba (1949) erected this species based on two Japanese specimens. Although he described the colour of the living animal and the buccal bulb, he did not illustrate the radular teeth or the reproductive system. When Haefelfinger and Stamm (1958) erected the genus Limenandra, they transferred B. fusiformis to this new genus. However, since the validity of Limenandra has been questioned for many years (e.g. Gosliner 1980, 1985), this species has been usually reported as B. fusiformis instead of L. fusiformis.

The anatomy of our specimens agrees well with the original description by Baba (1949). The long cerata have in L. fusiformis could be considered as diagnostic for this species since they do not occur in the other species described here. Additionally, the elongate ampulla of the reproductive system, which is described for the first time here, also distinguishes this species from the remaining species of the genus. Specimens from the Red Sea have some morphological differences from the Japanese specimens, such as cream body colour, so clearly, further material is required in order to confirm the presence of L. fusiformis in the Red Sea.

Limenandra barnosii sp. nov (Figs. 1c, 2, 3b, 5e, f, 6c)

Baeolidia sp. 3: Gosliner et al. (2008), 406

Limenandra sp. C: Carmona et al. (2013), 6

Type material Holotype: CASIZ 177682, one specimen, dissected, $30 \mathrm{~mm}$ in length preserved, Philippines, Luzon Island, Batangas Province, Balayan Bay, Matotonngil Point, collected by Terrence M. Gosliner, 19.iv.08. Paratype: CASIZ 182761, one specimen, dissected, $40 \mathrm{~mm}$ in length preserved, Philippines, Luzon Island, Batangas Province, Balayan Bay, Anilao, collected by Roger Steene, 16.v.10.

Type locality and habitat Balayan Bay, Batangas Province, Luzon Island, Philippines. Found in shallow water, in areas of mixed sand and rubble, feeding on the anemone Alicia sansibarensis.
Geographical distribution So far, only known from the Philippines, Indonesia and New Caledonia (Gosliner et al. 2008; present study).

Etymology This species is dedicated to Mohamed Barnosi, grandfather of the first author of this paper.

External morphology (Figs. 1c, 2, 3b): The body is elongate and slender, tapering close to the tail. The anterior margin of the foot is rounded. The tentaculiform foot corners have a deep groove across width (Fig. 2). The body colour is pale pink with lime green pigment all over the dorsum. The dorsal surface of the body from head to tail has series of concentric circles that are bright lemon yellow and pinkish purple inside. The number of circles varies with the size of the animal but up to fifteen. The edge of the foot alternates transverse translucent and lime green bands, which go from head to tail. The bases of the pink rhinophores are very close. They are densely papillate on posterior side, presenting orange colouration on the papillae. These papillae are elongate, not uniform in size and occasionally bifurcated (Fig. 3b). The oral tentacles are pinkish, elongate and longer than the rhinophores. The foot corners have same colour as the body and two lime green rings, the first one just below the pink tip and the second one at the midpoint.

The cerata are moderately long, fusiform and rounded. Their tips are slightly recurved inwards. The cerata are dark olive green with lime green pigments scattered all over their surface. Their distal part is pink and they have translucent tips. The cerata are arranged in up to twenty-five rows, from just behind the rhinophores to the end of the foot, and they are very close together every two rows. Some rows of cerata join over the dorsum and form an arch side-to-side with the opposite row. Each row contains 3-15 cerata, decreasing in size towards the foot. The anus is cleioproctic and is placed behind the third right row. The gonopore is located between right II and III rows on the right side.

Anatomy The buccal bulb has two jaws with a masticatory border finely denticulate (Fig. 5e). The radular formulae are $12 \times 0.1 .0$ (CASIZ 177682) and $11 \times 0.1 .0$ (CASIZ 182761). The radular teeth are wide with up to 66 moderately broad denticles (CASIZ 177682) (Fig. 5f). The teeth are progressively smaller to the posterior region of the radula. The oral glands lie dorsolaterally to the buccal bulb. They are moderately long and widest in the proximal end. Two pairs of salivary glands are present.

The reproductive system is diaulic (Fig. 6c). The preampullary duct widens into the conspicuous and elongate ampulla. The postampullary forks into the oviduct and vas deferens. The moderately long vas deferens enters the wider proximal portion of the penial sac, which contains 

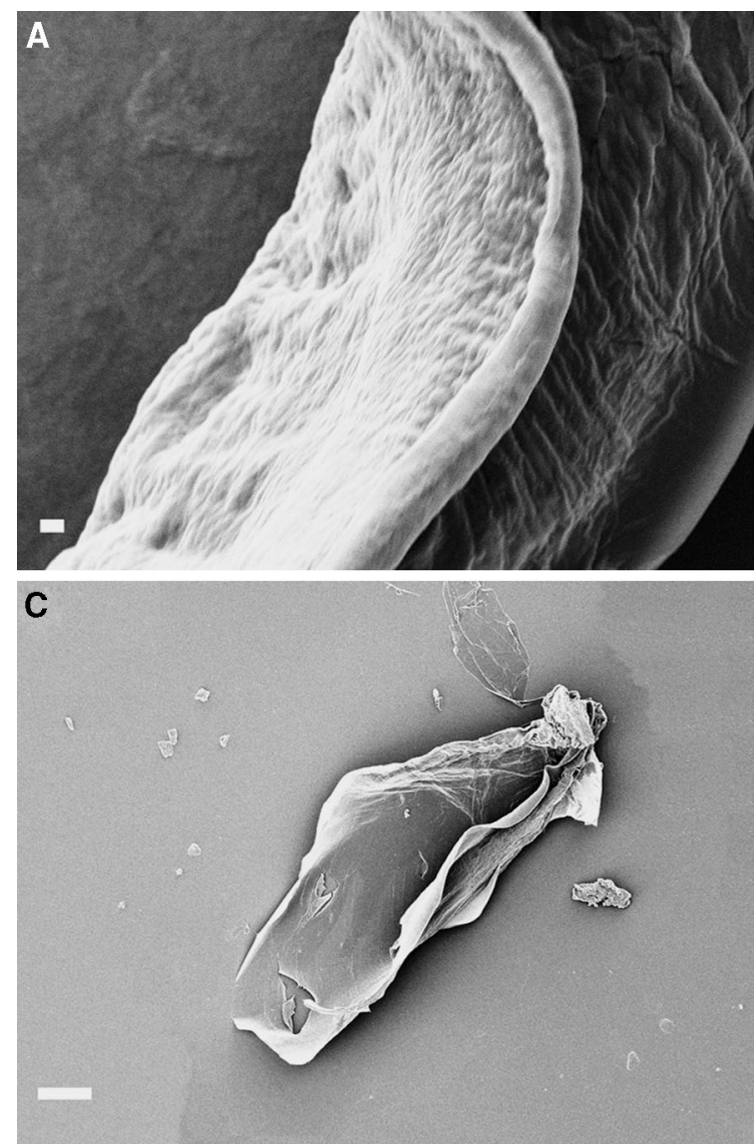

Fig. 7 Scanning electron photographs. a, b L. confusa sp. nov. (CASIZ 088358); a detailed view of the masticatory border, scale bar $2 \mu \mathrm{m}$; b radular teeth, scale bar $10 \mu \mathrm{m}$; c, d $L$. rosanae sp. nov.

the unarmed penial papilla. The long oviduct connects to a ball-shaped receptaculum seminis with a basal swelling. The remaining portion of the oviduct departs from the base of the receptaculum and enters the female gland. The vagina opens ventral to the penis.

Remarks Limenandra barnosii is easily distinguishable from other Limenandra species by its bright colours. It also differs from $L$. nodosa, L. confusa and $L$. fusiformis in the ornamentation, colouration and size of the cerata, the number of salivary glands and the reproductive system. While $L$. barnosii has smooth cerata, those of $L$. nodosa and $L$. confusa are often papillate. L. fusiformis also has smooth cerata, but some of them are significantly longer than the cerata of L. barnosii. Moreover, only L. barnosii has two pairs of salivary glands and a long oviduct leading from its junction with the vas deferens to the receptaculum seminis.

Limenandra confusa sp. nov (Figs. 1d, 2, 3a, 4, 6d, 7a, b) Baeolidia nodosa (Haefelfinger and Stamm 1958), non Haefelfinger and Stamm 1958: Gosliner 1980, 66-69, Fig. 19

Limenandra sp. A: Carmona et al. (2013), 6
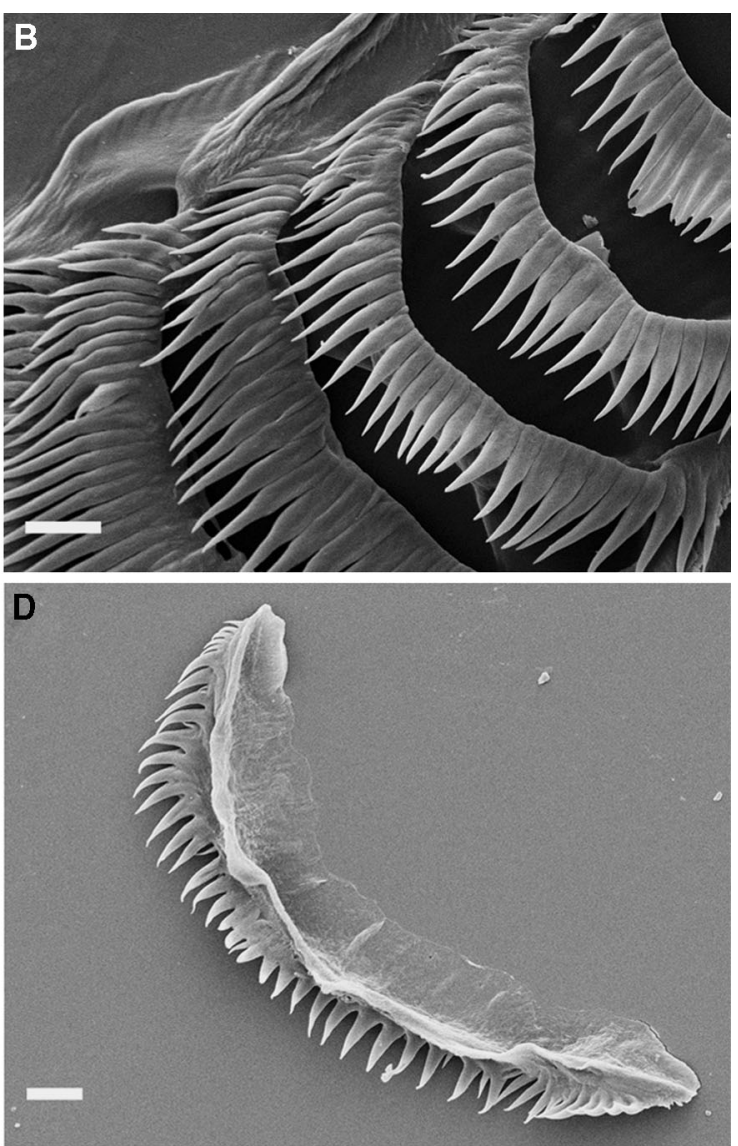

(CASIZ 106582); $\mathbf{c}$ detailed view of the masticatory border, scale bar $100 \mu \mathrm{m} ; \mathbf{d}$ radular teeth, scale bar $10 \mu \mathrm{m}$

Type material Holotype: CASIZ 088358 one specimen, dissected, $8 \mathrm{~mm}$ in length preserved, Midway Islands, South side of Sand Island, collected by Terrence M. Gosliner, 01.vi.93. Paratype: CASIZ 185991, one specimen, dissected, $3 \mathrm{~mm}$ in length preserved, Philippines, Luzon Island, Batangas Province, Balayan Bay, Anilao, Anilao Harbor, collected by Alicia Hermosillo, 30.v.11.

Other material CASIZ 181280, one specimen, $3 \mathrm{~mm}$ in length preserved, Philippines, Luzon, Batangas Province, Calumpan Peninsula, collected by Peri Paleracio, 21.v.09.

Type locality and habitat South side of Sand Island, Midway Islands. Found in shallow waters (3-10 m) under coral rumble, feeding upon small sea anemones.

Geographical distribution This species has been reported from the Indo-Pacific (Philippines) as well as the eastern Pacific: the Midway Islands (present study), Hawaii (Kay 1979; Gosliner 1980; Pittman and Fiene 2012a), Mexico (Gosliner et al. 2008), Gulf of California (Bertsch 1972) and Costa Rica (Camacho-García et al. 2005). 
Etymology The specific name refers to the mistakes previously made in identifying this species due to it close external morphological resemblance to $L$. nodosa.

External morphology (Figs. 1d, 2, 3a, 4): The body is slender and elongate, tapering close to the tail. The anterior margin of the foot is rounded. The foot corners are tentaculiform and have a deep groove across width (Fig. 2). The body colour is dull olive green with small white and cream spots over the notum. Series of concentric circles that are, from outside to inside, yellow, red and white in the centre, over the notum are found. The number of circles varies with the size of the animal. The rhinophores are dull green with small white and/or cream spots. The posterior side of the rhinophores has sparse papillae (Fig. 3a). These papillae are elongate and may be bifurcated. The apex is white or cream and rounded. The oral tentacles are elongate, longer than rhinophores. The oral tentacles and the foot corners are dull olive green with opaque white spots. The cerata are dorsoventrally flattened, some of them papillate (Fig. 4). They have the same body colour covered by white spots. The cerata are arranged in up to eleven rows, from just behind the rhinophores to the end of the foot, the first two rows very close together. The cerata of rows IV, VI, VIII and X (sometimes absent) are much longer than the rest. Each row contains 1-6 cerata, decreasing in size towards the foot. The cleioproctic anus is placed behind the third right row. The genital opening is located between rows II and III on the right.

Anatomy The jaws have a smooth masticatory edge (Fig. 7a). The radular formula is $9 \times 0.1 .0$ (CASIZ 088358). The radular teeth have a total of $20-40$ moderately broad denticles (CASIZ 088358) (Fig. 7b). The teeth are progressively smaller to the posterior region of the radula. Oral and salivary glands are present.

The reproductive system is diaulic (Fig. 6d). The preampullary duct widens into the conspicuous and short ampulla. The ampulla narrows again before dividing into the oviduct and vas deferens. The moderately long vas deferens enters the wider proximal portion of the penial sac, where the unarmed penial papilla is housed. The short oviduct connects to a rounded and large receptaculum seminis with a basal swelling. The remaining portion of the oviduct departs from the base of the receptaculum and enters the female gland. The vagina opens ventral to the penis.

Remarks Apart from the salivary glands and size of the receptaculum seminis, no morphological differences are found between $L$. nodosa and $L$. confusa. Since the oral glands can be easily misinterpreted for a piece of tissue or even missed or ignored, these glands usually do not appear in previous species descriptions. More studies are needed in order to confirm the validity of the salivary glands as a taxonomical character to distinguish species, but our observations may indicate the value of this anatomical feature.

Regarding the receptaculum seminis, $L$. confusa has a significantly larger receptaculum seminis than $L$. nodosa. When Gosliner (1980) reported L. confusa in Hawaii (under the name of $L$. nodosa), he also illustrated a large receptaculum seminis. Although more specimens of $L$. confusa would help to confirm the consistency of this morphological character, we consider the receptaculum seminis as the main morphological difference between L. nodosa and L. confusa.

Bertsch (1972) compared the characteristics of the radula, jaws, external colouration, cerata, size and rhinophores between one specimen of $L$. fusiformis and two specimens of " $L$. nodosa", one from the Mediterranean and the other from the Gulf of California (see Table 1 of that contribution). This author detected an overlap of these morphological traits but found some variability in colouration and shape of rhinophores. Nevertheless, Bertsch (1972) could not determine whether "these variations are all characteristic of one, two or three species". All the differences pointed out by Bertsch (1972) have been reviewed and rejected as no external differences were found between L. nodosa and L. confusa. However, Carmona et al. (2013) found genetic differences between these two species (minimum uncorrected $p$-distance $=7.3 \%$ for COI between $L$. nodosa and $L$. confusa, see Table 2 of that contribution). Recent studies supported by molecular phylogenies are starting to separate taxa with ecological or geographical differences (Claremont et al. 2011; Johnson and Gosliner 2012). Clearly, both species have distinct geographical patterns (Atlantic-Mediterranean for $L$. nodosa and Pacific for $L$. confusa). Thus, in view of the genetic, anatomical and biogeographic differences, we consider $L$. nodosa and $L$. confusa to be two sibling cryptic species.

Limenandra rosanae sp. nov (Figs. 2, 3b, 6e, 7c, d, $8 \mathrm{a}, \mathrm{b})$

Limenandra sp. 1: Ono (1999a)

Limenandra nodosa (Haefelfinger and Stamm 1958), non Haefelfinger and Stamm 1958: Ono 1999b: 168, first photo from the top

Baeolidia sp. 2: Gosliner et al. (2008), 406

Limenandra sp.: Yonow (2008), 253

Baeolidia sp. \#2: Pittman and Fiene (2012b)

Limenandra sp. B: Carmona et al. (2013), 6

Material examined Holotype: CASIZ 184522, one specimen, dissected, $15 \mathrm{~mm}$ in length preserved, Marshall 

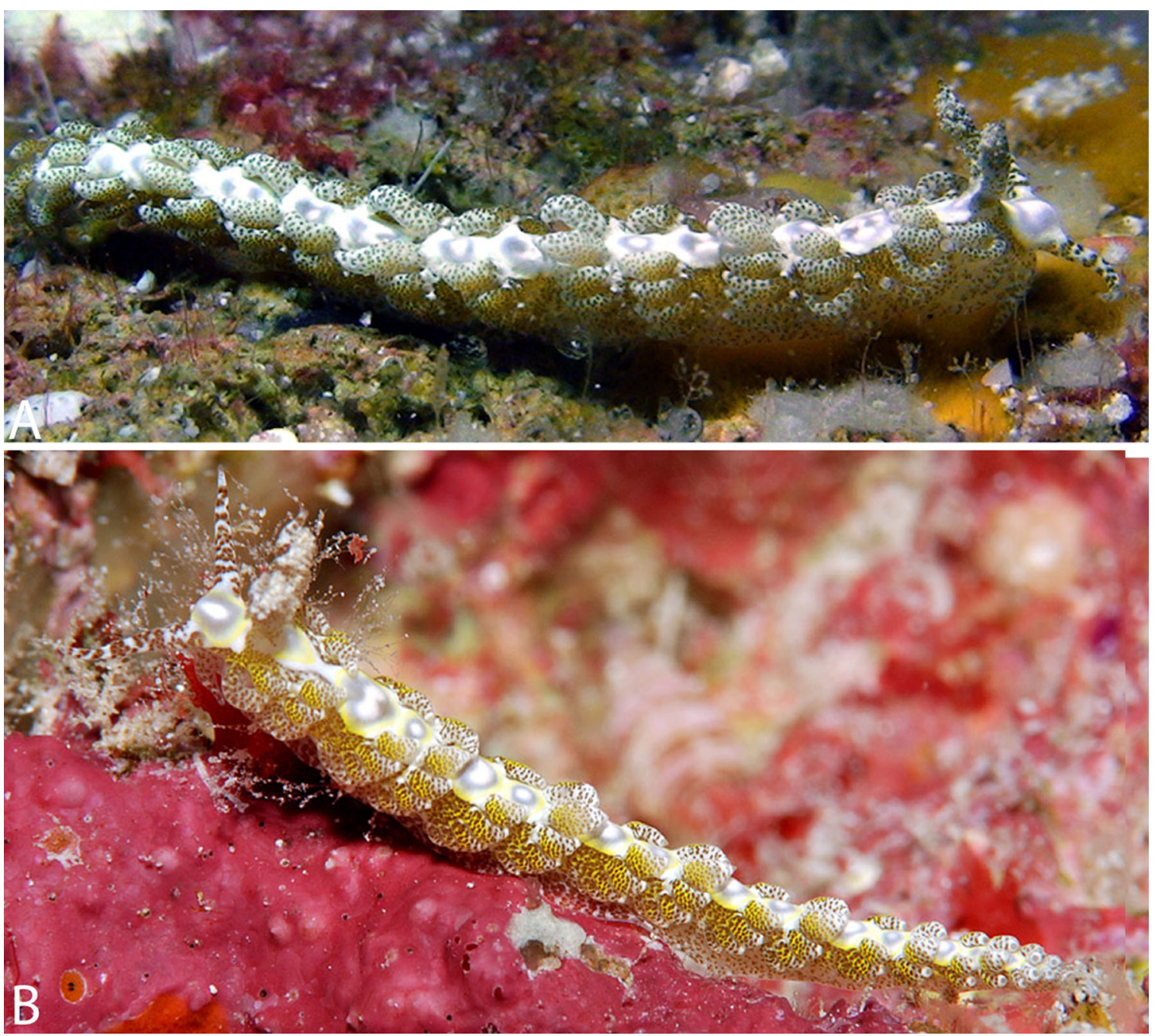

Fig. 8 Photographs of the living animals. a, b, L. rosanae sp. nov. specimens from the Marshall Islands, photographs by Scott Johnson, CASIZ 106582 and CASIZ 184528, respectively

Islands, Kwajalein Atoll, collected by Scott Johnson, 25.vi.09; Paratype: CASIZ 106582, one specimen, dissected, $2.5 \mathrm{~mm}$ in length preserved, Philippines, Luzon, Batangas Province, Maricaban Island, Cemetery Beach, collected by Terrence M. Gosliner, 15.iv.96.

Other material CASIZ 184528, one specimen, dissected, $9 \mathrm{~mm}$ in length preserved, Marshall Islands, Kwajalein Atoll, collected by Scott Johnson, 30.viii.09; ZSM Mol20052082, one specimen, dissected, $7 \mathrm{~mm}$ in length preserved, Samoa, 17.viii.05.

Geographical distribution Known from the Marshall Is. (present study), Hawaii (Gosliner et al. 2008; Pittman and Fiene 2012b), Samoa (present study), the Philippines (Gosliner et al. 2008) and the Kerama Is. (Ono 1999a, b). Also reported from the Red Sea (Yonow 2000, 2008).
Type locality and habitat Kwajalein Atoll, Marshall Islands. Found on shallow patch reefs in the vicinity of sea anemones.

Etymology This species is dedicated to Rosana Carvalho Schrödl, wife of Michael Schrödl who kindly gave us the first specimen of this species.

External morphology (Figs. 2, 3b, 8a, b): The body is elongate and slender, tapering close to the tail. The anterior margin of the foot is rounded. The tentaculiform foot corners have a deep groove across width (Fig. 2). The body colour is pearly white. The dorsal surface from head to tail has series of concentric circles that are bright lemon yellow (sometimes absent), bright grey and pearly white or pearly pink inside. In some specimens, these circles alternate with concentric circles of bright lemon yellow 
outside and bright grey in the centre. The number of circles depends on the size of the animal but may be up to fifteen. Small ochre or dark green/black spots together with bright yellow patches form a continuous band on each side of the body. The bases of the rhinophores are very close. The rhinophores are pearly white with the small ochre or dark green/black spots. They are densely papillate on posterior side. These papillae are elongate, not uniform in size, and may be bifurcated (Fig. 3b). Their apex is sharply rounded. The oral tentacles are elongate, longer than rhinophores. Both oral tentacles and foot corners have the same colour as the body, presenting the small ochre or dark green/black spots that are arranged in rings. The cerata are moderately short, fusiform and rounded. Their tips are slightly recurved towards the tail. The cerata are pearly white overlaid by ochre or dark green/black spots. Some specimens also have bright lemon yellow colouration on the outer side of the cerata. They are arranged in up to eighteen rows, from the rear of rhinophores to the end of the foot, separated by a small space every two rows. Each row contains 1-7 cerata, decreasing in size towards the foot. The anus is cleioproctic and is located behind the third right row. The genital aperture is placed between right II and III rows on the right.

Anatomy The jaws have a smooth masticatory border (Fig. 7c). The radular formulae are $4 \times 0.1 .0$ (CASIZ 106582) and $5 \times 0.1 .0$ (ZSM Mol-20052082). The radular teeth have a total of 18-33 moderately broad denticles (CASIZ 106582) (Fig. 7d). The teeth are progressively smaller to the posterior region of the radula. The oral glands lie dorsolaterally to the buccal bulb. They are moderately long and widest in the proximal end. Two pairs of salivary glands are present.

The reproductive system is diaulic (Fig. 6e). The preampullary duct widens into the wide and short ampulla, which narrows again before dividing into the oviduct and vas deferens. The vas deferens is usually conspicuous, although the specimen CASIZ 106582 has a thin and elongate vas deferens. This structure enters the wider proximal portion of the penial sac, which contains the unarmed penial papilla. The short oviduct connects to a large and pyriform receptaculum seminis with a basal swelling. The remaining portion of the oviduct departs from the base of the receptaculum and enters the female gland. The vagina opens ventral to the penis.

Remarks Limenandra rosanae is clearly distinguishable from other members of the genus because of its external colouration and its pyriform receptaculum seminis. Furthermore, this species differs from $L$. nodosa and $L$. confusa in having two salivary glands and in lacking long cerata or papillae on any cerata. L. barnosii also has a pair of salivary glands but differs in colouration.

\section{Discussion}

Phylogenetic analysis conducted by Carmona et al. (2013) strongly supported the monophyly and validity of the genus Limenandra, which had previously been considered a junior synonym of Baeolidia (Gosliner 1980, 1985; Redfern 2001; Camacho-García et al. 2005; Valdés et al. 2006; Gosliner et al. 2008). The original diagnosis of the genus proposed by Haefelfinger and Stamm (1958) clearly matches with our results. Nevertheless, the description of the rhinophoral papillae, the presence of concentric circles on the notum, the swelling of the receptaculum seminis and the small denticles on the masticatory border of some specimens should to be added to the diagnosis. We therefore amend the following diagnosis of the genus: body thin and elongate. Tentaculiform foot corners. Rhinophores papillate; the papillae elongate, irregular in size and sometimes bifurcated. Colouration pattern of concentric circles on the notum. Cerata in $8-25$ rows. They are fusiform, rounded and may be papillate. Radular teeth progressively smaller to the posterior region of the radula; pectinate without a distinct central cusp. Masticatory edge usually smooth. Receptaculum may have a basal swelling or a swelling at the base of the duct to the receptaculum.

This study shows that this small genus Limenandra of just five species so far has a mainly Indo-Pacific distribution, which agrees with the conclusions of Carmona et al. (2013). Only L. nodosa does not occur in the Indo-Pacific

Fig. 9 Phylogeny of Limenandra, based on Carmona et al. (2013). Names on right side of vertical bars refer to revised classification

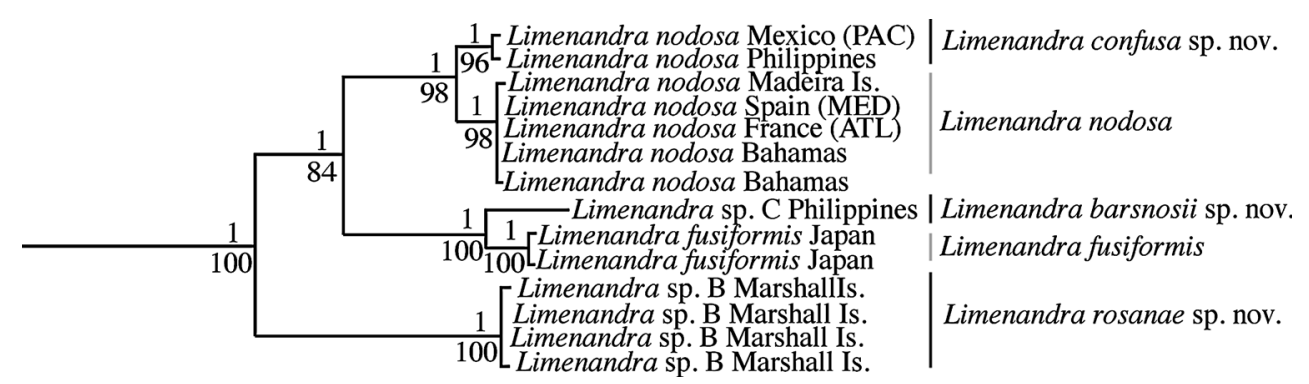


but is an amphiatlantic species. Figure 9 depicts the phylogenetic hypothesis presented by Carmona et al. (2013) resolving the phylogenetic relationships within the genus (names of the new species described here appear on the right side of vertical bars). According to Fig. 9, L. rosanae clusters in a separate basal clade. The second clade is divided into two subclades: one with $L$. confusa and L. nodosa as sister species and the second one with L. barnosii and L. fusiformis.

Acknowledgments We are deeply grateful to all individuals who helped to collect and provided specimens and images for this study, including Y. Camacho-García, M. Schrödl, C. Redfern, R. Nakano, M. Poddubetskaia, D. Behrens, C. Harris and S. Johnson. A. Sellas helped us with some molecular laboratory work. This work was supported by several research Grants CGL2006-05182/BOS, CTM2008-05228-E/MAR and CGL2010-17187, Spanish Ministry of Economy and Competitiveness (includes the early Ministry of Sciences and Innovation) to J. L. Cervera; Institut Menorquí d'Estudis, Balearic Is. to J. L. Cervera; California Academy of Sciences, National Science Foundation (DEB 0329054 PEET) to T. M. Gosliner; and a Research Grant of the Malacological Society of London to L. Carmona.

\section{References}

Baba K (1949) Opisthobranchia of Sagami Bay collected by His Majesty The Emperor of Japan. Iwanami Shoten, Tokyo

Bertsch H (1972) Two additions to the opisthobranch fauna of the Southern Gulf of California. Veliger 15:103-106

Camacho-García Y, Gosliner TM, Valdés Á (2005) Field guide to the sea slugs of the tropical Eastern Pacific. California Academy of Sciences, San Francisco, CA

Carmona L, Pola M, Gosliner TM, Cervera JL (2013) A tale that morphology fails to tell: a molecular phylogeny of Aeolidiidae (Aeolidida, Nudibranchia, Gastropoda). PloS One 8. doi:10. 1371/journal.pone.0063000

Cervera JL, Calado G, Gavaia C, Malaquias MAE, Templado J, Ballesteros M, García-Gómez JC, Megina C (2004) An annotated and updated checklist of the opisthobranchs (Mollusca: Gastropoda) from Spain and Portugal (including islands and archipelagos). Bol Inst Esp Oceanogr 20:1-122

Claremont M, Reid DG, Williams ST (2011) Evolution of corallivory in the gastropod genus Drupella. Coral Reefs 30:977-990

Franc A (1968) Sous-classe des opisthobranches. In: Grassé PP (ed) Traité de Zoologie. Masson, Paris, pp 608-893

García-Gómez JC, Cervera JL (1985) Revisión de Spurilla neapolitana Delle Chiaje 1823 (Mollusca: Nudibranchiata). J Molluscan Stud 51:138-156

Gosliner TM (1980) The systematics of the Aeolidacea (Nudibranchia: Mollusca) of the Hawaiian Islands, with description of two new species. Pac Sci 33:37-77
Gosliner TM (1985) The aeolid nudibranch family Aeolidiidae (Gastropoda, Opisthobranchia) from tropical southern Africa. Ann S Afr Mus 95:233-267

Gosliner TM, Behrens DW, Valdés Á (2008) Indo-Pacific nudibranchs and sea slugs. Sea Challengers/California Academy of Sciences, Gig Harbor, San Francisco, CA

Haefelfinger HR, Stamm RA (1958) Limenandra nodosa gen. et spec. nov. (Nudibranchia, Aeolidiidae prop.), un opisthobranche nouveau de la Méditerranée. Vie Milieu 9:418-423

Johnson RF, Gosliner TM (2012) Traditional taxonomic groupings mask evolutionary history: a molecular phylogeny and new classification of the chromodorid nudibranchs. PloS One 7. doi:10.1371/journal.pone.0033479

Kay EA (1979) Hawaiian marine shells, reef and shore fauna of Hawaii, section 4: Mollusca. Bernice P. Bishop Museum Special Publication 64(4)

Marcus Er, Marcus Ev (1970) Opisthobranchs from Curaçao and faunistically related regions. Stud Fauna Curaçao Caribbean Isl 33:1-129

Nakano R (2004) Opisthobranchs of Japan Islands. Rutles Inc, Tokyo

Ono A (1999a) Another species of Limenandra from Kerama Islands? [Message in] Sea Slug Forum. Australian Museum, Sydney. Available from http://www.seaslugforum.net/find/1215. Accessed November 2012

Ono A (1999b) Opisthobranchs of Kerama Islands. TBS-Britannica Co., Ltd., Tokyo

Ono A (2004) Opisthobranchs of Ryukyu Islands. Rutles, Inc., Tokyo

Pittman C, Fiene P (2012a) Baeolidia nodosa. [Message in] Sea Slugs of Hawaii. Available from http://seaslugsofhawaii.com/species/ Baeolidia-nodosa-a.html. Accessed November 2012

Pittman C, Fiene P (2012b) Baeolidia sp. \#2. [Message in] Sea Slugs of Hawaii. Available from http://seaslugsofhawaii.com/species/ Baeolidia-sp2-a.html. Accessed November 2012

Redfern C (2001) Bahamian Seashells: a thousand species from Abaco, Bahamas. Bahamianseashells.com Inc, Boca Raton, FL

Schmekel L (1970) Anatomie der Genitalorgane von Nudibranchiern (Gastropoda Euthyneura). PSZNI 38:120-217

Schmekel L, Portmann A (1982) Opisthobranchia des Mittelmeeres. Springer, Berlin

Templado J (1982) Nuevo opistobranquio para la malacofauna ibérica. Actas II Simposio Ibérico sobre los Estudios Bentos Marino 3:225-227

Valdés Á, Hamann J, Behrens DW, DuPont A (2006) Caribbean sea slugs. A field guide to the opisthobranch mollusks from the tropical northwestern Atlantic. Sea Challengers, Gig Harbor, WA

Yonow N (2000) Red Sea Opisthobrachia 4: the orders Cephalaspidea, Anaspidea, Notaspidea and Nudibranchia: Dendronotacea and Aeolidacea. Fauna Arabia 18:87-131

Yonow N (2008) Sea slugs of the Red Sea. Pensoft Publ, Sofía, Bulgaria 